From the Anat. Labor. of Prof. H. SETO, Tohoku University, Sendai.

\title{
Innervation, Especially, Sensory Innervation of Urethra in the Distal Part of Pig Penis.
}

\author{
豚陰茎前端部尿道の神経特飞知覚神経分布. \\ Naokichi ENDO 遠藤直吉. \\ [Received Februaxy 20, 1954.]
}

In 1939, SETO published an utterly dependable and brilliant report on his study of sensory innervation of the urethra in the pars cavernosa urethrae in human adult and embryo. Recently, NOBUTA (1948), one of his disciples, published his report on the same subject in the pars prostatica urethrae in man, resulting in far-reaching elucidation of sensory innervation of human urethra,

I herewith make a report of the study I have conducted on the innervation of the urethra of pig, in succession to my previously reported study on the innervation of the distal part of the pig penis, using the same set of numerous silver impregnated preparations ideally adapted to the observation of nerve fibres, as follows.

The urethra in the distal part of the pig penis is provided with many longitudinal numerous folds of varying sizes and the epithelium consists mainly of stratified columnar epithelium, which seems to be of transitional nature in places, with a little of stratified flat epithelium interspersed. The lamina propria under the epithelium consist of fibrous connective tissue abounding in elastic fibres, with an admixture of a small quantity of lengthwise running smooth muscle fibres, and forms at points weakly developed papillae against the epithelium. The boundary between the lamina propria mucosae and the surrounding weakvenal plexus is very indistinct, the two going over into each other in natural gradation. No urethral glands are found in the distal part of the penis.

The epithelium of the fossa navicularis urethrae is a little different from the human counterpart and consists mainly of stratified columnar epithelium, which gradually goes over into stratified flat epithelium as the external orifice is approached, but even its superficial flat epithelial cells are nuclear and living, showing no trace of cornification. The epithelium also shows considerable increase in thickness, and the papillar formation against it becomes more marked in development.

The nerves found in the mucous membrane of the urethra, coming through the corpus cavernosum urethrae, are represented as fine nerve 
bundles. These are supposed to originate in the branches of $n$. dorsalis penis distributing into the penis except the urethra. However, these nerves are not entirely similar to the nerves branching out into the glans penis, as the former consist of fine medullated fibres and a small

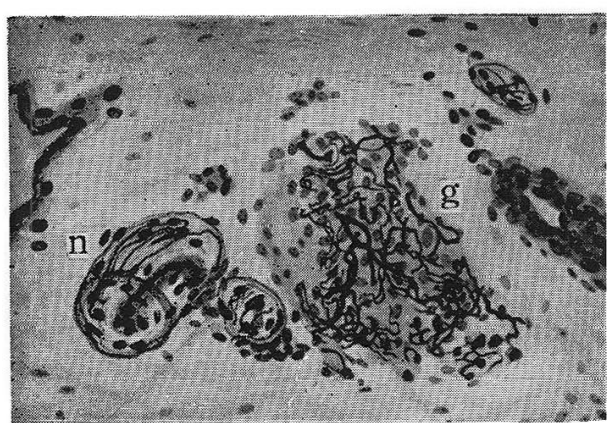

Fig. 1. A typical genital nerve body Type III (g) found in the periphery of lamina propria mucosae of urethra at the distal part of pig penis. $\boldsymbol{n}$ a nerve bundle consisting of one thick and four thin medullated fibres. SETO's silver impregnation. $\times 320$, reduced to $1 / 2$. number of thick medullated fibres, as shown in Fig. 1 and often include a small quantity of regetative fine nerve fibres.

The termination of the vegetative fibres is represented by the STÖHR's terminalreticulum also in the urethra as well as in other parts. It is found around the blood vessels including capillaries and also in the connective tissue of the lamina propria mucosae, to pass into the vicinity of the epithelium

of mucous membrane but never further into the epithelium itself.

The thick medullated fibres pass into the genital nerve bodies type III, as mentioned below, while the thin fibres end in simple branched and unbranched terminations. However, some branched endings are also found to originate in thick nerve fibres.

The sensory nerve fibres and their terminations are never strongly developed in the pig urethra, and stand far below in evolution to the human counterparts as described by Seto. Details on such nerve system follow hereunder.

SETO (1939) found the existence of genital nerve bodies type I (Fig. 6 in his report) in the lamina propria beneath the epithelium of human pars cavernosa urethrae, but no formation of similar endings has been observed in the pig urethra.

On the other hand, my genital bodies type III seem not to be found in human urethra, but it may be noted with interest that such bodies are not rarely found in the periphery of the proper membrane, that is, in the transitional connective tissue going over into the corpus cavernosum.

For example, a trpical genital body type III is shown in Fig. 1. This body has not any connective tissue capsule to speak of. A thick sensory fibre, losing its myelin. penetrates into an inner bulb containing 
many specific cell nuclei arranged irregularly, and undergoes a very complex typical arborized ramification. The terminal branches become gradually thinner and taper of into blunt or sharp ends after running peculiar meandering courses.

Directly under the epithelium of the pars cavernosa urethrae in man are frequently found branched sensory terminations showing very complicated patterns (Fig. 5 in SETO's report), but in the pig urethra, such terminations though existent, are far below in quantity and development. The specimen shown in Fig. 2, though rather finely developed for pigs, is seen as a simple branched termination consisting of only 3 branches which run out in extremely simple courses. This ending derives from a thick medullated fibre as may be seen in the figure, but such derivation is

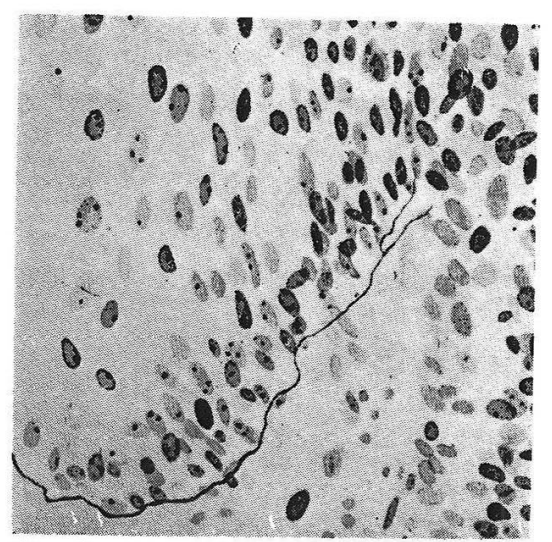

Fig. 2. A simple branched termination derived from a thick sensery fibre found in close vicinity of epithelium of urethra in the distal part of pig penis. Same staining. $\times 60(0$, reduced to $1 / 2$.

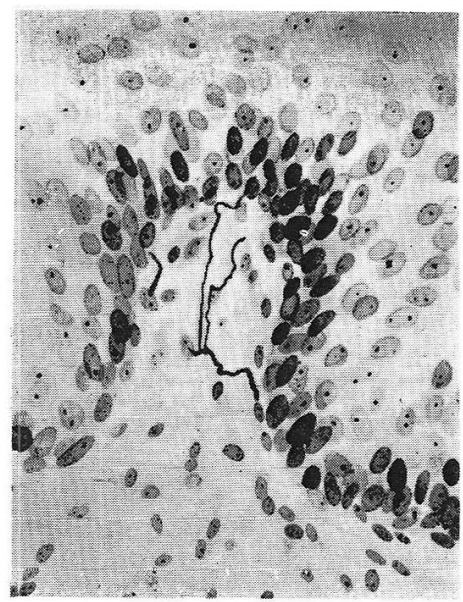

Fig. 3. A bifurcated termination of a fine medullated fibre found under the epithelium in fossa navicularis urethrae of pig penis. Same staining. $\times 600$, reduced to $1 / 2$.

rather a rare occurrence, most of such terminations originating in thin medullated fibres, and being composed of no more than 2 or 3 branches, as shown in Fig. 3.

Thus the branched terminations in the pig urethra are all of very simple conformation, and even simpler unbranched terminations, as shown in Fig. 4, are frequently found. These simplest of endings represent the majority of sensory terminations found in the mucous membrane of pig urethra. These consist of fibres, after loss of their myelin, running in a wave-like course near to the basis of the epithelium, without showing any considerable change in size, and come to a sharp termination.

In human urethra, there are 
found many intraepithelial nerve fibres ending in the epithelium proper, which show considerably intricate branching patterns, according to SETO, but in pig urethra, such intraepithelial fibres are very poorly developed, being found only on very rare oceasions and chiefly ending in simple unbranched endings.

Fig. 4 shows a terminal part of a thin sensory fibre ending un-

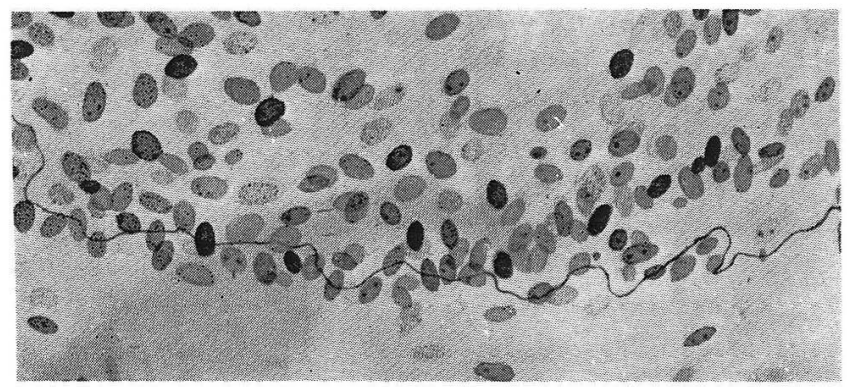

Fig. 4. A thin intraepithelial fibre of unbranched type found in fossa navicularis urethrae in pig penis. Same staining. $\times$ 600 , reduced to $1 / 2$.

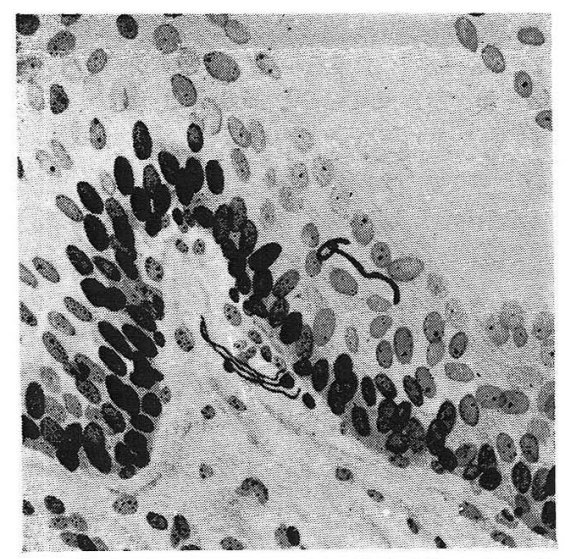

Fig. 5. A thick intraepithelial fibre found in the urethra in the distal part of pig penis. Same staining. $\times 600$, reduced to $1 / 2$.

branched found in the lamina propria mucosae at the distal part of pig urethra, which goes over into an intraepithelial fibre ending sharply in the epithelium. Fig. 5 shows an intraepithelial fibre represented by a thick sensory fibre found in the columnar epithelium in the corpus cavernosum urethrae posterior to the former. Such intraepithelial fibres originating in thick fibres are of rarest occurrence, most of the intraepithelial fibres coming from thin medullated fibres.

\section{Summary.}

The nerves penetrating into the mucous membrane of pars cavernosa urethrae in pig comprise a large number of thin medullated fibres and a small number of thick medullated fibres, including also a few vegetative nerve fibres.

The termination of regetative fibres is represented by STÖHR's 
terminalreticulum also in pig urethra.

The sensory nerve fibres and their terminations in pig urethra are far below in evolution in comparison with those in human urethra. The genital nerve bodies type III can be mentioned first as the sensory endings not rarely found in pig urethra. They originate from thick medullated fibres and are formed in the periphery of the lamina propria mucosae in main.

Branched terminations are also not rare and these are composed of 2 or 3 branches only. Unbranched terminations are the most numerous sensory terminations in the urethra. These two types of terminations come from the thin medullated fibres in general, and only rarely from thick fibres.

Intraepithelial fibres are in inferior stage of development and are represented by the unbranched type in all cases. These are derived mainly from thin medullated fibres but sometimes from thick medullated fibres.

\section{內 容自抄。}

豚尿道末㭻部に於ける知覚神経の発達は人間の夫（瀬戸）飞比すれば甚 だ劣勢である．知覚終末としては先ず陰部神経小体第III 型が挙げられる. 之は固有膜周辺部に稀ならず発見され，専ら太い有髄線維に由来する。次 飞非分岐性終末及び単純性分岐性終末が固有膜内飞形成される。前者は尿 道内知覚終末の中で最多を示める. 然し後者も亦少なからず発見される. 㖇者とも一般細い有䯣線維炕由来する。最後飞上皮内線維の発達は甚だ 劣勢で, 其大多数は非分岐性を示す.

\section{References.}

Nobuta : Tohoku Igaku Zassi. (Jap.) 39 (1948). P. 5. - Seto : Arb. Anat. Inst. Sendai. 22 (1939). S. 1. 